\title{
Rapid Spread of Settlements Endangers the Future of Historical Touristic Spice Farming in Zanzibar
}

\author{
Avit A Chami* \\ Department of Economic Studies; The Mwalimu Nyerere Memorial Academy, Tanzania \\ *Corresponding author: Avit A Chami, Department of Economic Studies; The Mwalimu Nyerere Memorial Academy, Tanzania
}

\section{Introduction}

Spice farming is one of the traditional practices which have been widely practiced in Zanzibar for centuries now. The extensively practiced spice production and trading in Zanzibar has made it be also known as "Spice Islands". The agricultural sector has a significant potential to the economy and livelihoods of people in many African countries [1]. The sector contributes $27 \%$ to Zanzibar's GDP and accounts for over $50 \%$ of foreign exchange earnings and employs $60 \%$ of the labour force in Zanzibar (ARIF, 2011). Spice farming is one of the most important crops in the agricultural sector in Zanzibar. Besides the agricultural sector, the spice sub-sector contributes to the development of the tourism sector which is the leading economic sector in the Zanzibar economy through spice tours.

Spices are vegetable products which are mostly used to enhance the food tastes, they are increasingly becoming important in our daily lives. Spices are mainly meant for flavouring, colouring, seasoning, preserving and imparting aroma in foods. Many spice crops are used in households' traditional cooking, healthcare, or other applications. Spices can be used to flavour bread, butter, meat, soups, and vegetables as well as make medicines and perfumes as appears in many countries around the world [2]. More than fifty spice plants have been reported to serve the global trade role and they are traded locally in many areas in the world [3]. Spices are usually grown inform of trees, shrubs, perennials, annuals, wild and cultivated [4]. Spice plants provide seeds and fruits, leaves and stems, flowers and buds, roots and rhizomes, bark and resins that can all be commercialized in various forms: sold fresh, frozen, dried, whole or ground, distilled into oils or solvent extracted into oleoresins $[3,5]$.

Recently there have been reported a good trade potential for small-scale spice farmers where growing conditions are favourable and there is a wide local market demand for spices and herbs in Zanzibar. This among other things has made spice farming serve the livelihoods of majority of smallholder farmers in Zanzibar Island
[6]. A large proportion of spices traded in both local and export markets are produced by small-scale farmers, and the worldwide trade provides massive earnings for small-scale farmers. This among other factors makes spice framing essential for income generation in rural areas and for the establishment of sustainable production system in semi-arid areas. The fact that smallholder farmers in Zanzibar mainly depend on subsistence farming and other sources of income, the spices farming activity tend to serve a very significant role to the livelihoods of majority of communities in Zanzibar, hence making spice farming become a high value crop in Zanzibar agriculture which contributes to $27 \%$ of the GDP [7], Spices play an important role in Zanzibar's history and economy. Currently the world market for spices is growing rapidly and the opportunity for developing countries to tap the market potential is huge [8]. Spice crops are serving many roles in many communities such that the cultivations of suitable spice and herb crops provide extra cash to supplement household income as well as providing an opportunity for women to start a commercial enterprise and be able to participate in the local economy. The income can be of great support, especially in case of widowhood or abandonment, and the enterprise can have the potential to provide a greater role for women in the family and community at large [7].

The spice farming in the world is passing through recession in these contemporary times due to ITC [6] argument that between 1995 and 1999, Tanzania ranked third by exporting 5\% of LDCs' total spice exports. During that period, spice crops marketing and export was conducted by the General Agricultural Foods Exporting Company (GAPEX). Since 2000s, after the GAPEX company was dissolved, Tanzania's share in the global spice trade was only $0.36 \%$ and it is estimated to have dropped further. However, spices under the agricultural sector and its related products are among priority sectors as stipulated in Zanzibar Export Development Strategies document [9], hence being of the high importance towards improving the livelihoods of communities. In line with prevailing great recession the spice farming sector, the recently reported rapid 
population growth in Zanzibar which automatically results to rapid expansion of settlements in various areas of Zanzibar, is envisaged to deprive the spice production as it reduces the available land for spice farming.

The rapid expansion of human settlements which is resulted from rapid population growth in Zanzibar, is envisaged to pose a stiff challenge to the agriculture sector in Zanzibar hence touching directly spice farming since cloves and spice-based products stand as distinctive traditional products from Zanzibar Island [6] It is undoubtedly that, agriculture sector in Zanzibar is invariably confounded by a number of challenges like many other regional states of the sub-Sahara Africa, the small size of available land compared to the ever-increasing population growth in the islands stands as the threatening challenge of all land-related economic activities. Following the recent findings in Chami et al. [10], rapid population growth which also directly implies settlement expansion was reported as a threatening challenge to all land-related economic activities including spice farming which is highly adopted by many smallholder farmers and widely linked to the tourism sector [11] This among other things calls for the need of undertaking land-use planning practices and re-allocation of new growing settlements so that the spread of settlements does not affect the available land for spice farming.

Need for putting much emphasis on land use planning practices is widely envisaged to be quite useful for the future of spice farming being a high value crop in Zanzibar since agriculture which contributes up to $27 \%$ of the GDP and a direct source of employment to about 42 percent of the population and contributes to more than a quarter of the national economy [7]. Zanzibar is a part of the United Republic of Tanzania consisting of two main islands of Unguja and Pemba with about 50 other small islets. The two main islands are $50 \mathrm{~km}$ apart separated by the 700 -metre-deep Pemba channel. The total surface area of the islands of Zanzibar is 2,654 square kilometers, Unguja, the larger of the two main islands has an area of 1,666 square kilometres, while Pemba has an area of 988 square kilometres. For a long time in history, agriculture has continued to be an important pillar to support livelihood of a larger proportion of people in Zanzibar $[6,7,11]$. According to ZATI [9] agriculture sector is responsible for ensuring food security by providing crops, livestock and marine products sufficient to feed over $1,000,000$ people residing in Zanzibar in the given time. According to the $5^{\text {th }}$ census after the union of Tanganyika and Zanzibar in 1964, the 2012 Population and Housing Census results show that, Tanzania has a population of 44,928,923 of which $43,625,354$ is on Tanzania Mainland and 1,303,569 is in Tanzania Zanzibar, there has been a rapid population growth over time hence causing a serious pressure on the fixed resources including land [12,13]. This among other things calls for the need of including proper land use planning practices in the policy frameworks in Zanzibar. This mini-review is a result of the empirical study which was carried in Kizimbani ward in Zanzibar where the factors affecting spice farming were ascertained among smallholder spice farmers.

\section{Acknowledgements}

I am exceedingly thankful to all smallholder spice farmers in Kizimbani ward in Zanzibar. Indeed, without their outstanding cooperation this study would have been impossible. I will always appreciate the lessons I learnt from smallholder farmers; they are very good teachers. However, the cordial cooperation rendered to me during data collection exercise by Shehas, Agricultural Officers and spice farmers groups leaders in the study area throughout the time of undertaking this study is highly appreciated.

\section{References}

1. Mahamoud II (2013) Inclusion of Small-Scale Farmers in the Spice Value Chain in Zanzibar, Tanzania. Master's Thesis: Governance, Policy and Political Economy (GPPE). Institute of Social Studies. The Hague, p. 49.

2. Shelaby A (2011) Value Chain Analysis for the Egyptian Herbs \& Spices Sub-Sector: Modeling and Estimating Export Potential.

3. FAO (2005) Herbs, Spice and Essential Oils: Post-harvest Operations in Developing Countries, by. Douglas, MJ Heyes and Small field B, Rome, p. 61.

4. Samaratunga PA (2007) Innovative Practice Sri Lanka: Integrating Small Farmers into Dynamic Supply-Chains: A Case Study of Ma's Tropical Fruit Company. Regoverning Markets Innovative Practice Series, IIED, London, p. 55-67.

5. Kledal PF, Eyhorn F, Elzakker B, Pereira EA (2013) The Possibilities for Inclusion of Smallholder Farmers in Organic Chain Development. In: Halberg, N. and Muller, A. (eds): Organic Agriculture for Sustainable Livelihoods, Earthscan, Routledge, pp. 154-173.

6. ITC (2014) International Trade Centre Report on Product Profile: Spice and Culinary Herbs. UNCTAD. Discussion Document. Brussels, p. 12.

7. Mlingi B, Rajab K (2009) Post-Harvest Losses Assessment. Ministry of Agriculture Livestock and Environment and FAO. Zanzibar, p. 88.

8. ITC (2001) International Trade Centre Report on Product Profile: Spice and Culinary Herbs. UNCTAD. Discussion Document. Brussels, p. 2.

9. ZATI (2009) Zanzibar Agricultural Transformation Initiative Report on Zanzibar Agricultural Transformation for Sustainable Development, (2010-2020). For Agricultural Productivity, Food Security and Sustainable Livelihood.

10. Chami AA, Mwadini MK, Ali ZM (2018) Socio-Economic Factors Affecting Spice Farming among Smallholder Farmers in Kizimbani Ward, Zanzibar. Tengeru Community Development Journal.

11. Revolutionary Government of Zanzibar (2010) The Zanzibar Strategy for Growth and Reduction of Poverty: 2010-2015 (ZSGRPII), MKUZA II, SMZ, Zanzibar, pp. 198.

12. United Republic of Tanzania (2013) National Population Census 2012. National Bureau of Statistics, Dar es Salaam, Tanzania, pp. 133.

13. United Republic of Tanzania (2010) Tanzania Demographic and Health Survey. Government Printers, Dar es Salaam, Tanzania, p. 18. 
(c) (i)

This work is licensed under Creative Commons Attribution 4.0 License

To Submit Your Article Click Here: Submit Article

DOI: $10.32474 /$ CIACR.2019.06.000238

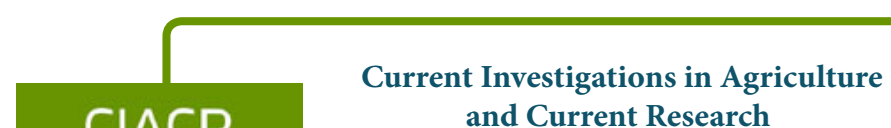
and Current Research

\section{Assets of Publishing with us}

- Global archiving of articles

- Immediate, unrestricted online access

- Rigorous Peer Review Process

- Authors Retain Copyrights

- Unique DOI for all articles 